\title{
Det rødes hjerte
}

\author{
Magisk realisme som kosmopolitisk regionalisme \\ i Zakes Mdas The Heart of Redness
}

ANN LANGWADT

I en ofte citeret forelæsning taler Homi Bhabha om (post)koloniale kulturers kosmopolitisme som værende affødt af mødet med kolonimagtens kultur, hvor sidstnævnte blev præsenteret for kolonierne som et sæt universelle goder der var eneste vej til dannelse, udvikling og fremskridt. Som Bhabha siger, har folk

ofte deres ide om fælles sprog fra post-oplysningstidens ideal om kosmopolitisk kultur - ideen om en klassisk kultur der er fælles og som skal læres. Mit argument er at vi har brug for en slags regional eller lokalsproget kosmopolitisme for at sætte spørgsmålstegn ved adskillelsen mellem centrale, kanoniske kulturer og hverdagskulturer. Dette kan gøres ved at prøve at forstå den enestående måde hvorpå koloniale kulturer selv var kosmopolitiske. ${ }^{\text {I }}$

Kolonierne var ikke bare passive modtagere af kolonisternes kultur, de tog dens redskaber til sig og brugte dem i nye udformninger og sprog og lærte at forholde sig til forskellige kulturer på mange planer. Bhabha mener derfor at kolonial kultur er kosmopolitisk verdenskultur, og at "hele den moderne verden er i færd med at forholde sig til spørgsmål som koloniale kulturer har skullet forholde sig til for længe siden" (op. cit.).

Som tidligere koloni har Sydafrika længe skullet forholde sig til 'verdenskulturen' i form af den europæiske dominans af Sydafrikas historie og samfund. Den 'nye' demokratiske sydafrikanske nation blev i 1994 født ind i en globaliseret tidsalder efter en lang national frihedskamp, som naturligt nok har fyldt meget i sydafrikansk litteratur. Dette essay vil præsentere en læsning af Zakes Mdas magiskrealistiske roman The Heart of Redness som bud på en rodfæstet kosmopolitisme der er kritisk over for mere traditionelle syn på modernitet og udvikling. ${ }^{2}$ Nutiden i Mdas roman The Heart of Redness foregår i det vi kalder post-apartheidtiden, men da apartheidtiden og den nationale frihedskamp nærmest bliver overset $\mathrm{i}$ romanen, er post-apartheid måske ikke den mest passende term for nutiden: dette er i sig selv en sjælden og interessant vinkel. I stedet for apartheid drejer romanens historie sig om det lokale i det globale; om xhosa-kultur og dens forhold til kolonialisme og anglo-amerikansk kultur. Den magisk-realistiske romangenres kendetegn og globale spredning synes for mig at gøre den særligt egnet til en diskussion af kosmopolitisk regionalisme.

Jim Goes to Jo’burg - Camagu Goes to Qolorha

Alle tekster fra den tredje verden er [...] allegoriske, og det på en ganske specifik måde: de skal læses som hvad jeg vil kalde nationale allegorier, selv når, eller måske især når deres form udspringer af hovedsageligt vestlige repræsentationsformer såsom romanen. 3

Sydafrika er nu blevet en nation hvor alle kan kalde sig sydafrikanere. Før koloniseringen ville de lokale have defineret sig som hørende til forskellige stammer (xhosa, zulu, khoikhoi, san, osv.); i anden halvdel af det tyvende århundrede forte apartheidregeringen en såkaldt 'hjemlandspolitik' ('homeland' eller 'Bantustan'), der gjorde at de sorte blev fremmede statsborgere i Sydafrika. Denne denationalisering var en del-og-hersk strategi der føjede stammeadskillelse til raceadskillelsespolitikken. Grundet denne politik var det for en tid problematisk for sorte at fokusere på stammetilhørsforhold, idet det 
syntes at understøtte apartheidregeringens politik på det etniske område og modarbejde den nationale modstandskamp. I dag er det dog igen blevet mere legitimt at beskæftige sig med etnicitet og stammetilhørsforhold i et demokrati, der i sin nationalforfatning forsøger at tilgodese både individuelle og gruppe-rettigheder såsom beskyttelse af de mindre sprog (Sydafrika har II nationalsprog).

Sydafrika er i den specielle situation at landet trådte ind på verdensscenen efter års isolation og skulle $i$ gang med at opbygge en nationalstat og national identitetsfølelse samtidig med at man i Vesten diskuterede nationalstaternes svækkelse under globaliseringen, og samtidig med at lokalbefolkningen igen fandt det legitimt at identificere sig $\mathrm{i}$ forhold til region og etnicitet og kræve at deres egen lokale historie blev optaget $\mathrm{i}$ den nationale historie. Under kolonialismen, der påberåbte sig en højere, universel autoritet og kosmopolitisk dannelse, skulle man uanset om man var pedi eller xhosa kende til Bibelen og Shakespeare; dernæst fulgte det tyvende århundredes modstandskamp (der ofte fandt kulturelt skyts i netop Bibelen og Shakespeare), der nødvendiggjorde en primært nationalistisk tilgang; men nu har apartheids fald åbnet op for nye og gamle varianter af regionalisme.

Njabulo S. Ndebeles "The Rediscovery of the Ordinary" (oprindeligt fra 1984) og Albie Sachs' "Preparing Ourselves for Freedom" (I989) er to eksempler på den sydafrikanske diskussion om kulturens rolle i modstandskampen. 4 Begge artikler påpeger at sydafrikansk litteratur var så bundet til anti-apartheid kampen at der nu var behov for en frihedskamp på det kulturelle plan også: en kamp mod det nationalistiske anti-apartheid-imperativ i sydafrikansk litteratur (Sachs foreslog med et glimt i øjet at ANC i 5 år skulle forbyde brugen af frasen 'kultur er et våben i kampen'). Langt den meste sorte litteratur foregik i storbyen, den moderne metropol, eller handlede om en person der rejste fra hjemegn (hjemland eller Bantustan) på landet til storbyen (i staten Sydafrika), typisk for at være (fremmed)arbejder i Johannesborgs miner. Genren kaldes 'Jim goes to Jo'burg', og næsten alle romanerne er skrevet af mænd og har mænd som hovedpersoner. Navnet Jim viser de hvides tradition for at give afrikanere nye navne der var nemmere at udtale for europæere, men demonstrerer bl.a. også anonymiseringen eller irrelevansen af Jims etniske tilhørsforhold: han er bare en hvilken som helst by - Bantu, for nu ikke at bruge apartheidtidens vidunderligt absurde betegnelse 'foreign native'. Mda har brudt med denne genre i sort sydafrikansk litteratur ved at tage udgangspunkt i sted snarere end i racisme eller apartheid, og hans historier foregår lige så ofte på landet som i byen. Mødet med moderniteten tager selvsagt en anden form for Mdas romanpersoner i landområderne end for dem i byerne. I The Heart of Redness vender Mda 'Jim goes to Jo'burg'-genren rundt og sender kosmopolitten Camagu fra by til land (måske tegn på en ny 'Camagu goes to Qolorha-genre'?). Det er også 'utraditionelt' at Mda skriver om sorte kulturer og traditioner, om interne forhold blandt sorte, frem for om den ellers allestedsnærværende konflikt imellem sorte og hvide, og i stedet netop skriver om det hverdagsagtige, som Ndebele efterlyste i sin artikel.

Mdas beskæftigelse med det hverdagsagtige finder form i en sydafrikansk eller xhosa magisk realisme. Mda trækker på de afrikanske fortælletraditioner (de samme som latinamerikanske forfattere trækker på via de afrikanske slavers mundtlige kultur), og pointerer at ordet 'magisk' kommer udefra: den vestlige forståelse af det magiske og det realistiske som modsætninger er ikke relevant for de mennesker, han skriver om eller for. ${ }^{5}$ Et forsimplet vestligt syn ville måske sige, at $i$ genrebegrebet magisk realisme står det 'magiske' for det indfødte (lokal, traditionel, regional, mundtlig, lokal folklore), og 'realisme' står for det vestlige (international, moderne, kosmopolitisk, skriftlig, vestlig romanform). Sådan en adskillelse af det traditionelle og det moderne hænger meget godt sammen med traditionel europæisk kritik af afrikansk litteratur og kultur, en kritik der tilsyneladende ikke har ændret sig meget siden Hegels forelæsninger over historiens filosofi (I822-3I). Hegel isolerede for argumentets skyld Afrika syd for Sahara, dømte det til at ligge uden for det historiske og mente derfor ikke at der var mere at sige om dette mørkets kontinent. ${ }^{6}$ Denne traditionelle historiefilosofi forestiller sig at historien har 
bevæget sig igennem verden ad én ret tidslinje fra øst til vest, fra Asien til Europa. Dette panoptiske syn på menneskedens udvikling dukker til stadighed op på forskellig vis i relation til sociale forhold i Afrika, hvor det traditionelle ses som tilbagestående eller primitivt, og det moderne som tegn på nødvendig og god udvikling: hvis man bor i en landsby, er det traditionelt; hvis man bor i en by, er det moderne; når en kvinde laver mad, er det traditionelt; når en mand laver mad, er det moderne.7 I litteraturen handler tvedelingen typisk om mundtlig over for skriftlig kultur, om fortælling som afrikansk tradition og romanen som importeret vestlig (moderne) kulturform.

Med den sydafrikanske nations indtrædelse i en verden der har et meget traditionelt syn på Afrika, ser man at den litterære kultur i Sydafrika stadig finder det nødvendigt at skabe positive billeder af afrikansk kultur - ikke kun for at rette op på apartheidtidens vrangbilleder, men også som en del af den meget større opgave, det er, at tage livet af Hegels spøgelse og ændre den traditionelle vestlige opfattelse af kontinentet og dets kulturer som værende, kort og groft sagt, irrelevante. Mda og andre sorte sydafrikanske forfattere er stadig sommetider offer for nogle vestlige kritikeres manglende interesse eller blindhed over for deres arbejde, hvilket kunne tyde på at Hegel stadig spøger iblandt os. ${ }^{8}$

Mdas magiske realisme er måske et udtryk for post-apartheid kunstnerisk frihed, og han formår både at opfylde Ndebeles krav om litteratur om sorte sydafrikaneres hverdag og at forblive politisk relevant. Han udtrykker sin kritik af nationale magthavere i det nye Sydafrika ligesom han gjorde i det gamle, men bruger lige så meget energi på at kritisere den transnationale anglo-amerikanske dominans af sydafrikansk kultur, politik og historie. 9 I The Heart of Redness finder vi dog ikke en omskrivning eller revision af historien som en Jamesonsk national allegori, men som en regionalistisk orienteret formulering der undgår at fremtræde etnocentrisk, som følgende præsentation af Mdas roman vil søge at vise.
Sort magi og $(H)$ videnskab: profeter og profitter $i$ The Heart of Redness

Titlen på Zakes Mdas fjerde roman The Heart of Redness refererer naturligvis til Joseph Conrads Heart of Darkness og inviterer dermed læseren til refleksion over det større perspektiv i europæisk kolonialisme i Afrika og kolonialismens globale strukturer igennem de seneste par århundreder. 'Redness' refererer i Mdas roman til den traditionelle okkerfarvede beklædning og kropsudsmykning brugt af xhosa-folket i den Østlige Kapprovins i Sydafrika. I stedet for Conrads Marlow sender Mda Camagu, hjemvendt til Sydafrika efter 30 års eksil i bl.a. USA, til 'det rødes hjerte'. Det rødes hjerte er hjertet af traditionelt xhosa-land, hvor det viser sig at traditionerne er ligeså meget til debat og under forandring som de altid har været. Udfordringerne af det traditionelle samfund vises $i$ romanen at have stærke paralleller $i$ kolonitiden og post-apartheid-tiden, og parallellerne smelter sammen i slutningen af romanen.

The Heart of Redness splitter historien op i to tidsrammer: midten af det nittende århundrede og slutningen af 1990'erne (romanens nutid); stedet er det samme, nemlig kystlandsbyen Qolorha. Den historiske fortælling foregår i I850'erne, hvor situationen er desperat for de lokale xhosaer som følge af omfattende kvægsygdom og konflikten med de engelske kolonister. En ung xhosa-pige, Nongqawuse, møder $i$ en vision forfædrene, som befaler xhosaerne at slagte alt deres kvæg og brænde deres afgrøder. Hvis de gør det, vil forfædrene komme ridende på havets bølger og redde xhosaerne ved at jage europæerne bort og fylde markerne med de flotteste afgrøder og kvæg. Denne profeti splitter xhosa-samfundet midt over i dem der tror på profetien ('Believers') og dem der ikke gør ('Unbelievers'). Som historien og romanen fortæller, førte den store xhosa-kvægslagtning i I 856-57 ikke til den spåede frelse: dagen kom og gik uden mirakler, der var ikke to sole på himlen, forfædrene viste sig ikke, og de Ikke-troende (mange xhosaer og alle europæere) blev ikke blæst til havs og druknet; tværtimod gjorde den efterfølgende hungersnød det nemmere for englænderne at stramme deres greb om landet. ${ }^{\text {Io }}$ Titusindvis af udsultede xhosaer måtte arbejde som slaver for ko- 
lonisterne for at overleve, alt imens diskussionen om profetierne fortsatte: var det de Ikke-troende xhosaers manglende lydighed, der havde forhindret profetierne $i$ at gå i opfyldelse; var profetierne falske; eller var profetierne måske ligefrem planlagt af englænderne som redskab $i$ invasionen af xhosaernes land? Mda præsenterer disse diskussioner igennem forfaderen Xikixas Troende og Ikke-troende efterkommere i det nittende og tyvende århundrede.

I det nittende århundrede beskrives konflikten i historien om Xixikas tvillingesønner Twin og TwinTwin. Twin er Troende ('rød'), Twin-Twin Ikke-troende; Twin er gift med Qukezwa, en khoikhoi kvinde med hvem han har et barn, Heitsi; Twin-Twin har mange koner, mange børn og stor rigdom. ${ }^{I I} \mathrm{Hi}-$ storien fortæller hvordan profetierne splittede samfundet ad på alle planer, brødre blev fjender, mænd blev skilt fra deres koner, og Troende destruerede Ikke-troendes landbrug, kvæg og hjem og tvang dem på flugt. Twin og Twin-Twin bliver dødsfjender, og Twin-Twin overlever kvægslagtningen medens Twin dør som sindssyg på et fattighjem. Qukezwa nægter at modtage hjælp både fra englænderne og de Ikke-troende, så hun og Heitsi overlever så godt de kan ved havet. De Ikke-troende blev af de Troende betragtet som værende kollaboratører og forrædere, fordi de ligesom kolonisterne afviste profetierne og dermed den eneste chance for at slippe af med englænderne, og fordi Ikke-troende fik ly hos kolonisterne hvorved de reddede en del kvæg og afgrøder.

Umiddelbart kunne det se ud som om xhosasamfundet nedbryder sig selv med sin 'tilbageståenhed' (den irrationelle og blinde tro på en katastrofal profeti) og at kun dem der tilpasser sig kolonisternes 'udvikling' af området overlever - en tilpasning der kræver at xhosa traditioner aflives. I sydafrikansk historieundervisning under det hvide styre er Nonqawuse-historien da også netop blevet brugt til at illustrere ikke bare det uundgåelige, men også det nødvendige og gode ved udvikling og modernisering efter vestlig model; altså at de hvide egentligt har søgt at 'redde' de sorte sydafrikanerne fra deres egen selvdestruktive og tilbagestående traditionalisme. Romanen præsenterer dog et langt mere komplekst billede, der bl.a. viser forståelse for troen på Nonqawuse's profeti i den desperate situation xhosaerne befandt sig i: man kan ikke se ned på mennesker der griber efter den eneste chance for frelse eller frihed de kan se. Romanen viser hvor desperate xhosaerne var og hvor brændende de ønskede sig fri for europæerne - ikke at traditionerne nødvendigvis altid må vige for udviklingens skyld. Romanen giver mange eksempler på hvordan det traditionelle og det moderne, det magiske og det realistiske, findes i begge af konfliktens lejre. For eksempel blev Twin og Twin-Twin's fader, Xikixa, der er kendt som den hovedløse forfader, taget til fange af englænderne i det nittende århundrede, og sønnerne ser hvordan englænderne skærer hans hoved af og koger det $\mathrm{i}$ en gryde. Xhosaerne betragter denne handling ud fra deres egne traditioner for 'krigsmagi', der også indbefattede lemlæstelse af døde fjender. Englænderne oplyser dem dog om at denne kranieafkogning skam står for det modsatte af xhosaernes barbariske handlinger og at Xikixas kranium vil blive bragt tilbage til England som souvenir eller for at blive brugt til videnskabelige undersøgelser. Xhosaernes fornuftige respons på denne oplysning er: "Souvenirs.Videnskabelig undersøgelse. Det gav ingen mening. Det var simpelthen den hvide mands heksekunst". ${ }^{12}$ Det var naturligvis netop i denne periode, $i$ anden halvdel af det nittende århundrede, at den videnskabelige racisme (eller social Darwinisme) skulle nå nye højder, hvilket gav de hvide kolonister 'mod' og motivation - med andre ord, 'krigsmagi' - i deres kampe mod og undertrykkelse af afrikanske folkeslag. Igen, forskellen mellem engelske og xhosa traditioner viser sig at være mindre (eller af en anden art) end englænderne påstår: påstanden bæres af kolonisternes økonomiske og militære magt snarere end af en egentlig modsætning imellem såkaldt uciviliserede xhosa-traditioner og civiliseret engelsk videnskab, eller sort magi i modsætning til (h)videnskab. Ifølge romanen er den europæiske modsætning imellem engelsk kultur og xhosa traditioner altså stillet forkert op, og romanen viser $\mathrm{i}$ den nutidige tidsramme at diskussionen om det moderne og det traditionelle stadigvæk føres på forkerte præmisser. Blandt Twin og Twin-Twins 
efterkommere i I990'erne ulmer den gamle konflikt stadig, men her sender Mda en 'forsoner', Camagu, ind $\mathrm{i}$ dens hjerte. ${ }^{13}$

Camagu, der er midt i 40 'erne, er vendt hjem til det nye demokratiske Sydafrika efter 30 år i eksil, hvor han bl.a. har arbejdet som kommunikationsog udviklingsrådgiver for UNESCO i USA. Dette giver ham de perfekte baggrundsmæssige kvalifikationer for sin rolle i romanen. Efter fire års forgæves jobsøgning i Johannesburg bringer forskellige mere eller mindre tilfældige omstændigheder ham til Qolorha, hvor han ankommer som en sjælden sort sydafrikansk turist klædt i fashionabelt vestafrikansk tøj. Camagu dumper ned lige midt i landsbyens bitre debat om etableringen af et moderne feriekompleks ved kysten.

Feriekomplekset er planlagt af et stort firma der lover udvikling til landsbyens beboere, men Camagu og andre kan nok regne ud at de lokales jobkvalifikationer ikke helt svarer til kravene (croupier, hotel manager, surfe-instruktør, massør, osv.) og at der højst vil være ufaglærte jobs til nogle få af beboerne, medens firmaet vil score den store profit af 'udviklingen'. Jo mere entusiastisk firmaets mænd beskriver projektet som en blanding af en amerikansk forlystelsespark og engelsk landskab med jetski, kasino, og vejnavne der ender på 'Dell' og 'Close', jo mere bliver det klart at denne udvikling fuldstændigt vil erodere det eksisterende landskab og den lokale kultur. Planen repræsenterer ikke en modernisering af det lokale, men modernisering $i$ stedet for det lokale. Camagu går til modangreb ved at fremføre sine planer om at skaffe en fredningserklæring på Nonqawuses egn. Parallellen til diskussionen $\mathrm{i}$ det nittende århundrede etableres her endnu engang, idet Nongqawuses profeti talte om at forfædrene ville komme ridende på havets bølger og redde xhosaerne, og kapitalismens profeter, firmaets Mr. Smith og Mr. Jones, matcher dette ved at forsikre at landsbyen vil blive reddet når turisterne kommer ridende på deres surfboards. Igen stiller Xikixas efterkommere sig stejlt på hver sin side $\mathrm{i}$ debatten, og begreberne tradition og modernitet, af debattens deltagere typisk sidestillet med xhosa-kultur og anglo-amerikansk kultur, er atter de foretrukne verbale våben. Camagu bliver personligt involveret i sagen på grund af sin interesse for to lokale kvinder der repræsenterer hver sin side: Xoliswa Ximiya, den vestligt orienterede datter af den Ikke-troende patriarch Bhonco, og Qukezwa Zim, der respekterer den lokale økologi, kultur og historie, og som er datter af den Troende Zim.

Xoliswa er dybt flov over den stædige overlevelse af xhosa traditioner i landsbyen og især over historien om Nonqawuse. Hun er overbevist om at hvide mennesker er civilisationens og fremskridtets bærere også for Qolorha, og at feriekomplekset vil 'oplyse' landsbybeboerne og befri dem for deres 'rødhed'. På magisk-realistisk vis lader den historiske arv dog ikke Xoliswa være i fred: hun arver de Ikke-troendes historiske ar på ryggen som klør hver gang de Troende irriterer hende. Disse ar opstod første gang hos Twin-Twin i forbindelse med hans irritation og uforsonlige holdning over for Twin, og Xoliswa arver dem fra sin far Bhonco.

På den anden side står Qukezwa, datter af den Troende Zim, som kan tale med fuglene. Hun bærer samme navn som Twins kone i I850'erne og kalder ligesom hende sin søn Heitsi. Heitsi er resultatet af en jomfrufødsel, selvom Camagu var 'i nærheden' ved undfangelsen (det var en 'magisk' oplevelse, som han længes efter at gøre til en del af sin hverdag). Denne jomfrufødsel er et af eksemplerne på, hvordan Mda forbinder xhosa og khoi tro med kristendom, en forbindelse der til dels kan spores til kriger-profeten Mlanjenis synkretisering af kristendom og xhosa tro i det nittende århundrede, og til udvekslingen mellem disse religioner og khoiernes tro (f.eks. skilte profeten Heitsi flodens vande ligesom Moses). Qukezwa (i begge romanens tidsrammer) står for overlevelse og overlevering af xhosa traditioner, og hun demonstrerer lighederne imellem xhosa og engelske traditioner og 'magi'. Den nutidige Quekzwa tror på en udvikling i Qolorha som ikke destruerer al lokalkultur, så hun ønsker en (absolut moderne) form for natur- og kulturturisme der viser respekt for stedet, frem for at ændre hele landskabet til et anonymt, historieløst vandland for rige turister. Qukezwa er meget miljøbevidst og gør hvad hun kan for at redde den lokale flora, f.eks. 
ved at gå til angreb på de importerede træer der er skadelige for den. Her er hun i tråd både med moderne miljøpolitik og med den lokale tradition, for Kong Sarhili havde på Nonqawuses tid fredet en del af egnen som naturreservat. Hendes aktivisme på dette punkt leder til en komisk diskussion om fordelene ved lokale eller importerede planter og træer, hvor, forudsigeligt, de Troende og de Ikke-troende stiller sig stejlt op mod hinanden. De Ikke-troende mener jo at alt godt kommer udefra og at alt lokalt er primitivt, så diskussionen om flora vedhæftes også resten af begreberne fra det binære sæt: udenlandske planter er civiliserede, lokale planter er uciviliserede, osv. Man skulle her måske tro at Qukezwa helt går i okker, men sådan er det ikke: hun respekterer sine forfædres tro og traditioner, som var en amalgamering af xhosa, khoi og vestlig tro og traditioner, men hun lever i nutiden, og ud over hendes moderne videnskabelige viden om økosystemet symboliserer Mda dette bl.a. ved at give hende en uldhue på med et Pierre Cardin logo.

Camagu vælger Qukezwa, eller rettere, han bliver valgt af hende. Han bliver uvenner med Xoliswa da han begynder at vise forståelse for Qukezwas synspunkter, og det bliver ikke bedre da han fortæller Xoliswa om sit møde med sit klantotem, amaMpondomiseklanens Majola slange, som han respekterer og tillægger stor betydning. Xoliswa er chokeret over at denne næsten-amerikanske og derfor meget civiliserede mand er så overtroisk, at han tror på noget så primitivt som et klantotem, for hun er overbevist om at mennesker i den moderne verden har lagt alle former for overtro bag sig.

Hvis man går ind på romanpersonernes præsentation af konflikten som værende mellem tradition og modernitet (magi og realisme), så vælger den desillusionerede tidligere eksil-sydafrikaner traditionen frem for moderniteten, men romanens pointe er netop at det ikke er der, den egentlige konflikt ligger. Tradition og modernitet er ikke to faste enten - eller størrelser som defineret af Vesten eller Xoliswa, og okker behøver ikke at være en hindring for modernisering. Okker gør ikke nødvendigvis bæreren traditionel, ligesom et digitalur på håndleddet ikke nødvendigvis gør bæreren moderne.
Som den Ikke-troende Bhoncos kone NoPetticoat siger, er der måske i virkeligheden forskellige veje til fremskridt og udvikling, og der kan være en pris at betale uanset hvilken vej man vælger. Da NoPetticoat en dag vælger at skifte fra vestlig beklædning til xhosa beklædning ser hendes mand det som det ultimative forræderi, på linje med de Troendes i det nittende århundrede: "dette har gjort hende til en forræder over for familiemedlemmerne [...] Endnu engang har de Troende vundet et slag. Kun et slag, ikke krigen. Krigen kommer til at trække ud. De Ikke-troende vil sejre til sidst, for de har civilisationen på deres side. Står det ikke skrevet at mørkets kræfter vil blive besejret?" I4 - hvor man skal bemærke at Bhonco refererer til det skrevne, da en del af konflikten jo netop står imellem det skrevne (vestlige) og det mundtlige (xhosa).

\section{Magisk realisme og KKK (Kolonialisme, Kapitalisme og} Kristendom)

Forholdet imellem, eller synkretiseringen af det mundtlige og det skriftlige er et element der kendetegner den magisk-realistiske genre (og megen postkolonial litteratur generelt). I The Heart of Redness lærer vi om Tsiqwa, Skaber-Faderen, som Qukezwa beder til, Tsiqwa "der fortæller sine historier i himlen: Han som skabte Khoikhoierne og hele verden", ${ }^{5}$ og som repræsenterer den mundtlige oprindelse af alle verdens fortælletraditioner. Qukezwa beder både i det nittende og det tyvende århundrede til Tsiqwa og viderefører dermed denne tradition, der har inkorporeret elementer fra de andre religiøse traditioner den har været i kontakt med og er blevet en del af xhosa tradition. Der er mange eksempler på magisk-realistisk kommunikation mellem nulevende og afdøde eller endnu ufødte, hvilket til tider generer de Ikke-troende, især når det handler om den pinlige Nonqawuse-historie som de gerne så begravet og glemt. De Ikke-troendes flovhed over deres egen kultur bliver straffet med "historiens ar" på ryggen: når Bhonco og siden hen hans datter Xoliswa prøver at vende ryggen til de åbenlyse tegn på, at historien er en del af nutiden og fremtiden, klør deres nedarvede ar på ryggen. I Bhonco og Zims bitre konkurrence bliver der også appelleret til de 
afdøde, og forfædrenes budbringere, såsom fugle og bier, bliver sat på forskellige opgaver i dysten.

Mda benytter sig af xhosa magisk realisme for at fortælle en historie om forholdet mellem det regionale og det globale hvortil genren er specielt velegnet. Den regionale historie finder sin relation til det globale og overlever tilsyneladende. Nogle kritikere vil dog mene at dette synspunkt er urealistisk og at, som Michael Valdez Moses skriver,

'Magisk realisme' udtrykker den globale modernitets nostalgi for de traditionelle verdener den har besejret og subsumeret. Langt fra at repræsentere et alternativ til eller undergravning af den nye verdensorden viser magisk realisme sig at være både en effekt af og et redskab for globalisering, der i sig selv blot er den seneste fase i en århundredlang moderniseringsproces [...] dens vej til global prominens antyder at den magisk-realistiske roman er en [...] nutidig manifestation af tilblivelsen af hvad Goethe kaldte 'Verdenslitteratur' [...] sådanne transnationale og translingvistiske udvekslinger er ikke uden fortilfælde [...] Men disse tidligere kosmopolitiske genrer opnåede ikke at være populære $i$ hele verden på en gang sådan som den magisk-realistiske genre er det nu. ${ }^{16}$

Jeg mener at Mdas magiske realisme er mere end en nostalgisk længsel efter en verden der accepteres som værende død eller døende. Romanen viser at de mundtlige og magiske elementer $\mathrm{i}$ xhosa kultur allerede var synkretiseret med khoikhoiernes og kolonisternes kultur i det nittende århundrede og før, og at den levende xhosa kultur, selv i det rødes hjerte, er under stadig forandring. Mda vækker ikke Nonqawuses spøgelse til live for at græde over det forgangne; han vækker hende tværtimod så hun kan tage livet af andre gamle spøgelser, såsom Hegels, hvis traditionelle syn på Afrika ikke er blevet stedt til hvile af nok så megen modernitet.

Den sydafrikanske kritiker Brenda Cooper mener at "magisk realisme opstår i en bestemt type samfund - postkoloniale lande, lande hvor udviklingen er ujævn og hvor nyt og gammelt, moderne og oldtids, og videnskab og magi eksisterer side om side". ${ }^{17}$ Disse forhold er dog ikke ukendte i Vesten, hvor, f.eks., moderne europæere og nordamerikanere går i kirke og dyrker troen på deres traditio- nelle magi - som altså også eksisterer side om side med det moderne videnskabelige samfund. Moses' kritik af magisk realisme mangler efter min mening blik for tilstedeværelsen af det magiske i Vesten og for dets magt i vestlige samfunds sociale forhold og historie. Moses' binære opdeling, der tager sit udgangspunkt i vestlig periodeopdeling ("moderne og præmoderne, det realistiske og det magiske, det vestlige og det ikke-vestlige", op.cit.), minder om den problematiske opdeling der deler hele historien op i præ-kolonial, kolonial, og post-kolonial, hvor det forudsættes at der kun findes det vestlige udgangspunkt, og at Afrika ikke har nogen historie udover konflikten med Vesten. ${ }^{18}$ Moses' adskillelse af det traditionelle (magiske, okkulte) og det moderne (realistiske, rationelle) er for snæver: han ignorerer kristendommen (og andre religioner) og dens magt, og kun den manøvre gør ham i stand til at delegere 'magi' til den tredje verden og 'realisme' til Vesten. ${ }^{19}$ Når Moses taler om den moderne verdens sejr over det traditionelle og magiske, så måtte man deraf lede at moderniteten har ophævet kristendommen, og det er dog langt fra tilfældet: det traditionelle og magiske lever videre under stadig forandring og $\mathrm{i}$ nye udformninger, både i Vesten og i Afrika.

\section{Rodfestet kosmopolitisme}

Det lykkedes i sidste ende Camagu at få fodfæste i landsbyen, at blive gift med Qukezwa og blive involveret i udviklingen af området der bliver erklæret fredet som national kulturarv - med Nonqawuses hjælp. At stedet erklæres national kulturarv demonstrerer at regionalisme udmærket kan gøre brug af nationale rettigheder. Camagu (hvis baggrund er baseret på Mdas egne oplevelser som hjemvendt verdensborger) og Qukezwa lever begge op til Josna Rege's definition af rodfæstet kosmopolitisme, der I) hverken romantiserer en idealiseret tradition eller ser vestlig modernitet som eneste vej til frihed; bruger den del af traditionen, der er nyttig i den forhåndenværende situation, men også elementer fra andre traditioner; insisterer på sine rettigheder i den moderne nationalstat. 2) er bevidst om at lokalsamfundet kan være undertrykkende og $\mathrm{i}$ intern konflikt; fejrer, men ikke feticherer forskelle imel- 
lem mennesker eller grupper; søger at finde fælles interesser. 3) har øje for de eksisterende hierarkier $i$ magt og privilegier, og for sin egen position $\mathrm{i}$ dem. 4) vælger at arbejde lokalt uden $\operatorname{dog}$ at se mennesker og etiske valg udelukkende igennem en lokal linse. ${ }^{\circ}$ Qukezwa, den unge landsbykvinde uden megen skoleuddannelse, har fundet sin egen vinkel på modernisering, en regional vinkel, hvis styrke hurtigt bliver opfattet af Camagu, den veluddannede verdensborger, og Camagu og Qukezwas forening (efter megen forhandling parterne imellem) kan dermed ses som et symbol for den kosmopolitiske regionalisme der bliver Qolorhas udviklingsstrategi.

The Heart of Redness er ikke en nostalgisk længen tilbage til præ-koloniale xhosa traditioner, men en udforskning af hvordan disse traditioner kan finde berettigelse i nutiden og endda bruges politisk som modstand mod den homogeniserende anglo-amerikanske kultur-invasion og transnationale storkapital, når det er dét, lokalbefolkningen ønsker. Og hvad angår Mdas læsere, så er de ikke kun at finde blandt Moses' nostalgiske moderne vesterlændinge: i modsætning til hans mere internationalt berømte hvide forfatterkolleger har Mda faktisk et stort sydafrikansk publikum.

Mda er hverken en etnocentrisk hjemstavnsforfatter eller en forfatter der leverer den eksotiske vare efterspurgt af desillusionerede postmoderne vesterlændinge. Trods brugen af magisk realisme er hans perspektiv ikke nostalgisk eller sentimentalt (Moses) eller national-allegorisk (Jameson). Han er en forfatter der med sit kosmopolitisk-regionalistiske perspektiv og den magisk-realistiske form demonstrerer Bhabhas ideer om postkoloniale nationers og regioners bidrag til en ny, kritisk kosmopolitisme. ${ }^{21}$

\section{Noter}

I. Jeff Makos, "Rethinking Experience of Countries with Colonial Past". The University of Chicago Chronicle, I4 (I2), I6 Feb I995. http://chronicle.uchicago.edu/9502I6/ bhabha.shtm. Alle oversættelser til dansk af AL.

2. Zakes, Mda: The Heart of Redness. Oxford: Oxford UP, 200o. Dette er Mdas tredje af fem romaner; derudover er Mda forfatter til mere end 30 teaterstykker. Mda begyndte først at udgive romaner efter apartheidregimets fald. 3. Fredric Jameson, "Third-World Literature in the Era of
Multinational Capitalism”. Social Text, I5, I986: 69. 4. Njabulo S. Ndebele, "The Rediscovery of the Ordinary”. Journal of Southern African Studies, I2 (2), April 1986. Albie Sachs, "Preparing Ourselves for Freedom". I Writing South Africa. Literature, Apartheid, and Democracy, 1970-1995. Red. Derek Attridge \& Rosemary Jolly. Cambridge: Cambridge UP, 1998.

5. "Another writer who has possibly influenced me is Gabriel García Márquez, whose work draws very strongly from the oral tradition of African slaves. Mine also draws from that oral tradition [....] My work will always have that intertextuality, unlike Coetzee's with the Western canon [.... I draw from the same sources as the creators of magical realism hence the 'magic'. I say 'magic' in quotes, you see, because the work from which my fiction draws hasn't got that line of demarcation between the supernatural on one hand and what you would call objective reality on the other hand. [....] What in the Western world you consider as magic is part of their day-to-day lives [....] part of their realism [....] part of their real world". "An Interview with Zakes Mda” af John B. Kachuba. http://africaspeaks.com/ reasoning/board=books; action=display;num = $\mathbf{I} 093374959$. 6. G.W.F. Hegel, The Philosophy of History. New York: Dover Publications, 1956. "Africa proper, as far as History goes back, has remained - for all purposes of connection with the rest of the World - shut up; it is the Gold-land compressed within itself - the land of childhood, which lying beyond the day of history, is enveloped in the dark mantle of Night [.... The peculiarly African character is difficult to comprehend, for the very reason that in reference to it, we must give up the principle which naturally accompanies all our ideas - the category of Universality [.... Africa proper - the Upland [is] almost entirely unknown to us" (s. 9I-93).

7. For diskussion af kønsdifferentieret kosmopolitanisme i Afrika, se f.eks. Mojúbàolú Olúfúnké Okome “African Women and Power: Reflections on the Perils of Unwarranted Cosmopolitanism". Jenda: A Journal of Culture and African Women Studies, I.I (2000). http://www.jendajournal.com/.

8. Lars Bonnevie (forfatter og litteraturanmelder ved Weekendavisen) informerede $\mathrm{i}$ et foredrag om sydafrikansk litteratur (Diamanten, København, november 2004) publikum om, at sort sydafrikansk litteratur generelt var journalistisk, propagandistisk og ikke interessant som litteratur. Han kunne godt nok ikke nævne navnet på en eneste nutidig sort sydafrikansk forfatter, men mente åbenbart han alligevel kunne sige, at det ikke var værd at læse (hvilket uvægerligt mindede mig om Hegel, der i sin historiefilosofi skrev at han intet vidste om Afrika syd for Sahara, andet end at der ikke var noget at vide - se note 6).

9. Til trods for romanens kritiske holdning til nationalpolitikere har Sydafrikas tidligere miljø- og turistminister, 
Valli Moosa, bifaldende citeret fra The Heart of Redness $\mathrm{i}$ parlamentet.Valli Moosa "Lend a Hand for Sustainable Development, People, Planet and Prosperity" (Budget Vote Speech of the Minister of Environmental Affairs and Tourism), 9 Maj 2002. http://www.info.gov.za/speeches/2002/0205I0II46I00I.htm.

Io.Det vurderes at ca. 40000 xhosaer sultede ihjel og 400000 kvæg blev slagtet. Leonard Thompson, A History of South Africa. New Haven \& London:Yale UP, I990: 79. II.Heitsi er opkaldt efter Heitsi Eibib, khoikhoiernes første profet og søn af skaber-faderen Tsiqwa. Khoikhoierne, der er blandt Sydafrikas ældste folkeslag, blev af europæerne tidligere kaldet 'hottentotter'.

12. The Heart of Redness, s. $2 \mathrm{I}$.

I3. Camagus navn betyder 'forsoner'. "Camagu! Interjection. Be gracious! Be pacified! Be appeased! (addressed to ancestral spirits, witchdoctors, and displeased chiefs); camagu, noun: a witchdoctor offering a proprietory sacrifice; one who uses charms to bring about peace" (J. McLaren A New Concise Xhosa-English Dictionary. $3^{\text {rd }}$ ed. Pinelands (Cape Town): Maskew Miller Longman, 1963).

I4. The Heart of Redness, s. 269.

I5. The Heart of Redness, s. 23.

I6. Michael Valdez Moses, "Magical Realism at World's End", Margin. http://www.angelfire.com/wa2/margin/ nonficMoses.html. Der refereres ofte til 'Goethes Verdenslitteratur', men Goethes ide og ideal er naturligvis af sin tid og sidestiller praktisk talt verdenslitteratur med europæisk litteratur (Christopher Prendergast "The World Republic of Letters”, i C. Prendergast, red., Debating World Literature. London \& New York: Verso, 2004).

I7. Brenda Cooper, Magical Realism in West African Fiction: Seeing with a Third Eye. London: Routledge, 1998: 2 I6.
I8. Og hvis de har, er det sådan noget som den 'uorden' man har set i Rwanda og Burundi, og som får nogle til nostalgisk at ønske at Vesten kunne træde ind som $\mathrm{i}$ 'de gode gamle dage' og bringe lov og orden ved at kolonisere territorierne igen - se f.eks. Robert Cooper "Why We Still Need Empires”, The Observer, 7. april 2002.http://observer. guardian.co.uk/worldview/story/o, II58I,680 II 7,00.html. I9. Det magiske eller my(s)tiske er ikke uden politisk slagkraft, hverken for afrikanere eller for vesterlændinge. Vestens tilstedeværelse i Afrika i dag, hvoraf en vigtig del f.eks. repræsenteres af missionærer og amerikanske dollars, demonstrerer rigeligt traditionen for irrationel eller uvidenskabelig vestlig 'oplysning', såsom prædikener om seksuel afholdenhed og katolske missionærers rituelle kondomafbrændinger, der er finansieret af vestlige kirker og regeringer - en 'Dommedag Nu'-taktik af proportioner, der i det AIDS-ramte Afrika langt overgår den store xhosa kvægslagtning i I856-7.

20.Josna Rege "Women and the New Cosmopolitanism". Curricular Crossings: Women's Studies and Area Studies. http://womencrossing.org/rege.html.

2r.Endnu et litterært eksempel på Mdas kosmopolitiske regionalisme kan forventes $\mathrm{i}$ fremtiden, da Mda for tiden arbejder på en ny roman der igen er inspireret af sted, og igen ikke af hjemstavn. Mda opholder sig meget i Ohio, hvor han underviser, og synet af et fattigt boligområde (en 'Hooverville') i Appalachian-bjergene inspirerede Mda til at gå i gang med en fortælling om dets lokale beboere, de såkaldte WIN-folk (White, Indian, Negro). Julie Wark, “Interview with Zakes Mda”, 2004. http://www.zakesmda.com/pages/Interview_Wark.html. 


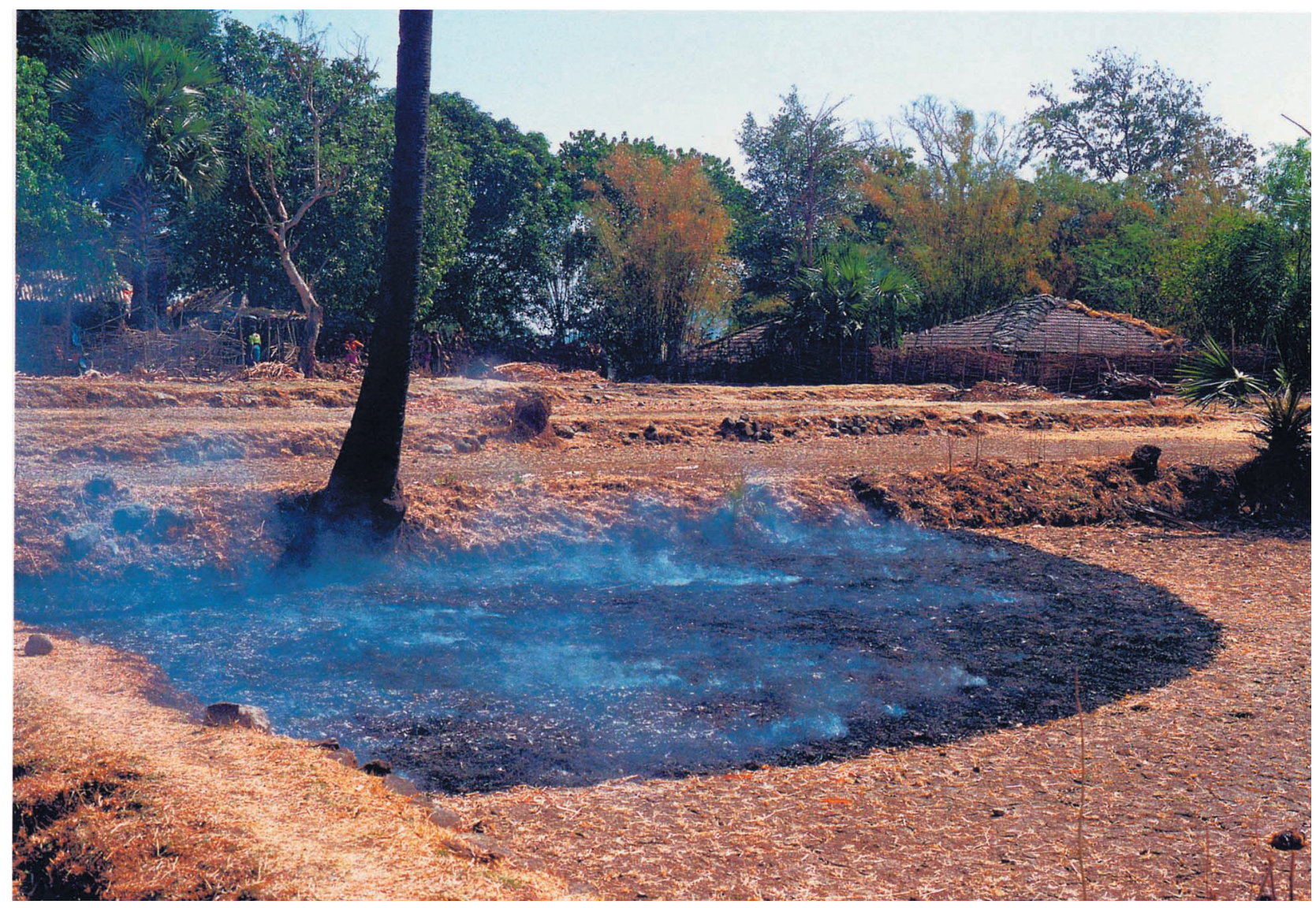

SMOKY ARC, WARLI TRIBAL LAND, MAHARASHTRA INDIA 2003

photograph 80 x I2O CM (C) Richard Long, med tilladelse fra Haunch of Venison, London 